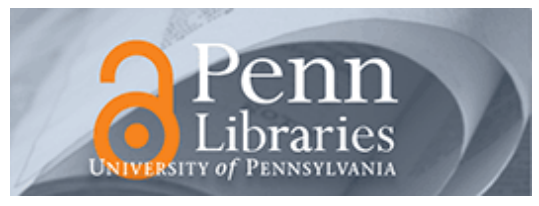

University of Pennsylvania

ScholarlyCommons

Management Papers

Wharton Faculty Research

6-2003

\title{
Why Focus? A Study Of Intra-Industry Focus Effects
}

Nicolaj Siggelkow

University of Pennsylvania

Follow this and additional works at: https://repository.upenn.edu/mgmt_papers

Part of the Business Administration, Management, and Operations Commons

\section{Recommended Citation}

Siggelkow, N. (2003). Why Focus? A Study Of Intra-Industry Focus Effects. The Journal of Industrial Economics, 51 (2), 121-150. http://dx.doi.org/10.1111/1467-6451.00195

This paper is posted at ScholarlyCommons. https://repository.upenn.edu/mgmt_papers/50

For more information, please contact repository@pobox.upenn.edu. 


\title{
Why Focus? A Study Of Intra-Industry Focus Effects
}

\begin{abstract}
In an intra-industry setting, firm-focus is found to be positively correlated with the ability of firms to produce high-value products, while the overall effect of focus on firm performance is negative due to missed demand externalities generated by a broad product offering. In particular, it is shown that U.S. mutual funds that belong to more focused fund providers outperform similar funds offered by more diversified providers. An explanation based on alignment among a provider's activities is consistent with this result. Cash inflows into fund providers-a measure related to fund provider profitability-is, however, negatively correlated with focus in fund offerings.
\end{abstract}

Disciplines

Business Administration, Management, and Operations 


\title{
Why Focus? A Study of Intra-Industry Focus Effects
}

\author{
Nicolaj Siggelkow \\ Management Department \\ Wharton School \\ 2017 Steinberg Hall - Dietrich Hall \\ University of Pennsylvania \\ Philadelphia, PA 19104 \\ siggelkow@wharton.upenn.edu \\ tel: (215) 573-7137
}

\begin{abstract}
While the effects of focus have been studied primarily in the context of diversification across industries, a study of focus within one industry can further our understanding of the drivers that underlie focus effects. In particular, we study the effects of focus in the mutual fund industry. We find that funds belonging to more focused fund families outperform similar funds in more diversified families. Moreover, it is the relatedness among funds within a family, rather than the mere narrowness of product offering, which is responsible for this positive focus effect. Total cash inflows into fund families are, however, negatively affected by family focus. Since focus boosts the return of individual funds but reduces the scale of the total fund family, and thereby the fees that fund families receive, the interests of fund shareholders and the incentives of the owners of mutual fund families are potentially in conflict.
\end{abstract}

Draft Date: December 11, 1998

I would like to thank George Baker, Richard Caves, Pankaj Ghemawat, Tarun Khanna, Cynthia Montgomery, Michael Porter, Jan Rivkin, and Peter Tufano for helpful comments. All remaining errors are mine. I am grateful to the Division of Research of the Harvard Business School for financial support. 


\section{$\underline{\text { Introduction }}$}

The relationship between diversification and the performance of firms has received ample attention in both the industrial organization and finance literature (e.g., Wernerfelt and Montgomery 1988, Lang and Stulz 1994). Almost exclusively, however, existing research has studied firms which diversify across industries. In contrast, we explore the effect of firm focus within an industry. Thus, we move the discussion and analysis of firm focus from the corporate to the business unit level. This move allows us to explore empirically the drivers of a focus effect. Moreover, by restricting the analysis to one industry, we gain a deeper understanding of how firms operate within this industry, allowing us to provide richer explanations of our findings.

In particular, we examine the effects of focus within the mutual fund industry over the period 1985-1996. We explore whether a mutual fund that belongs to a focused fund family has higher returns than similar funds that belong to more diversified families. Furthermore, to analyze the drivers of the focus effect, we test whether a mutual fund (e.g., a conservative corporate bond fund) benefits from belonging to a family which specializes on that particular type of fund, or whether funds benefit from merely belonging to a family with a narrow product portfolio, regardless of whether the family specializes on that particular type of fund or not. In other words, we test whether the focus effect is driven by relatedness or by narrowness of the product portfolio.

While the relationship between fund performance and family focus is of particular interest to fund shareholders, the relationship between cash inflows into fund families and family focus is of interest to the owners of the fund families (i.e., the owners of the investment management company offering the funds). Therefore, to assess whether the 
interests of fund shareholders and the incentives of fund family owners are aligned with respect to family focus, we study how cash inflows into families are affected by the focus of fund families.

The mutual fund industry is particularly attractive for a study of intra-industry focus effects for three reasons. First, to disentangle the drivers of a focus effect it is essential to have performance data at the sub-business unit level. In most industries, this data is difficult to obtain. ${ }^{1}$ In the mutual fund industry, however, firms are required to disclose the performance of each individual fund, i.e., each product in the offering of a mutual fund family. Second, the performance measure is relatively precise in contrast to, for instance, accounting returns for business units, or quality measures for individual products. Third, all funds have basically the same access to the main input in this industry, i.e., securities from which fund managers select their portfolios. Thus, in this setting, focus effects cannot arise from some firms' having cornered a part of the input market. Moreover, there are strong forces at work to make this input market efficient. In sum, the mutual fund industry is a particularly demanding setting for a test of the effects of focus.

Apart from its virtues as an arena to conduct a focus study, the mutual fund industry deserves the attention not only of the finance profession, but also of strategy scholars, industrial organization economists, and policy makers. Following enormous growth over the past decade, by the end of 1996 , the mutual fund industry managed more than $\$ 3.5$ trillion in assets, making it the second largest financial intermediary in the U.S. behind commercial banks. By 1996, more than 30 million households had invested in mutual funds, either through an individual investment account or through a retirement account. 
Thus, understanding the determinants of mutual fund performance and inquiring into potential agency problems in this industry have become important undertakings.

This paper is organized as follows: Section I briefly reviews the related literature. In Section II, we describe the organization of mutual fund families and discuss possible sources of a focus effect in this industry. Section III describes a classification scheme for mutual funds, and the focus-, performance-, and flow-measures which are used in the analysis. Section IV reports the relationship between focus and fund performance and analyzes the drivers of the focus effect. In Section $\mathrm{V}$ we explore the relationship between focus and cash flows into fund families. Section VI concludes.

\section{$\underline{\text { I. Brief literature review }}$}

The literature on diversification is so voluminous that even a brief review would require an extraordinary amount of space. As a result, the following overview is at best impressionistic.

Most of the industrial organization literature on diversification analyzes the relationship between the performance of firms and a general, one-dimensional measure of diversification. Studies use Herfindahl-like measures (e.g., Montgomery 1985, Scherer and

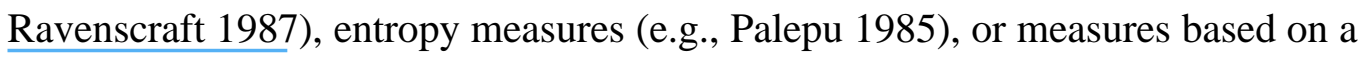
concentric index introduced by Caves et al. (1980) which takes into account the relatedness among business units (e.g., Montgomery and Wernerfelt 1988). These studies

find either a neutral or a slightly negative relationship between the degree of diversification and performance (for a survey, see Montgomery 1994). 
Within the industrial organization literature, the study closest in structure to the one presented in this paper is conducted by Lichtenberg (1992), who tests for the effect of diversification on plant productivity. Lichtenberg finds that the larger the number of industries in which a parent firm operates, the lower the productivity of its plants (holding constant the number of parent-firm plants).

With respect to diversification, the finance literature has analyzed the impact of acquisition and divestitures on firm performance. For instance, Morck, Shleifer, and Vishny (1990) find that in the 1980s more bidders in related acquisitions had positive returns than bidders in unrelated acquisitions. Similarly, Comment and Jarrell (1995) and John and Ofek (1995) find that divesting unrelated divisions leads to increased performance, while Daley, Mehotra, and Sivakumar (1997) find that cross-industry spinoffs create more value than own-industry spinoffs. ${ }^{2}$

Given these results, it is natural to ask why focus should yield higher returns than broad diversification. Explanations can be divided into two groups, using as a criterion whether the proposed benefit accrues only to units the firm is focusing on (but not to "lone stragglers" within the firm), or whether the benefit accrues to all units. Explanations of the first kind are based on arguments of "relatedness" whereas explanations of the second kind are based on arguments of "narrowness."

Explanations based on relatedness include the following: Montgomery (1985) argues that broad diversification is associated with low market power in the individual markets in which a firm operates. Thus, only units on which a firm is focusing (i.e., where a firm has sufficient market share to exercise market power) should generate higher profitability. 
A second reason is given by Montgomery and Wernerfelt (1988), who argue that as firms employ excess capacity of less-than-perfectly marketable resources (Penrose 1959,

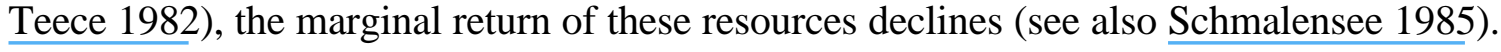
Hence, we would expect a negative correlation between the distance of a business unit from the core of the firm and the profitability of this business unit.

A third explanation emphasizes the fit and complementarities among various choices a firm makes (Milgrom and Roberts 1990, 1995; Porter 1996). Focus can enable a firm to align its activities in a very specific manner, thereby enabling it to generate either a better product or a product at a lower cost than a less focused firm. Following this line of reasoning, we will describe in Section II.2 some particular misalignments that can arise when a mutual fund family attempts to satisfy too many customer demands with respect to fund types. ${ }^{3}$

Explanations that are based on the narrowness of a firm's strategy include Meyer, Milgrom, and Roberts (1992), who show that a reduction of the number of businesses a firm is engaged in can reduce influence costs within a firm. ${ }^{4}$ Using an agency-theoretic set-up, Rotemberg and Saloner (1994) show how the narrowness of business strategies can facilitate the provision of incentives. These explanations imply that even units within a firm that do not belong to a group of businesses on which the firm is focusing would still benefit from the narrowness of the firm's strategy. By using variables that distinguish between relatedness and narrowness, we will be able to shed some empirical light on the impact of these two sources of a focus effect.

In the literature on mutual funds, the effect of focus on fund performance and on cash inflows into families has not been studied previously. However, we benefit from the 
substantial research analyzing the performance of mutual funds as compared to market indices in constructing performance measures and identifying relevant control variables (e.g., Jensen 1968, Blake, Elton, and Gruber 1992, Gruber 1996).

One further study that is related to the present analysis is conducted by Makadok and Walker (1996). While these authors pursue a very different goal in their paper-to analyze whether search behavior within a specified stochastic growth system affects fund family exit in the money market mutual fund industry - they estimate a performance regression which includes a focus-like variable. In their model, focus is measured by the number of money market funds a family is offering. They find that fund performance and product breadth are negatively correlated.

To motivate our choice of variables which measure focus in this industry, the following section provides a brief description of the organization of mutual fund families and describes possible sources of a focus effect.

\section{II.1. The organization of mutual fund families}

In broad terms, a mutual fund is a company that invests on behalf of individual investors who share a similar investment goal. Each mutual fund consists of a board of directors and the capital paid in by fund shareholders (see Figure 1). Formally, the board

of directors hires an investment management company to operate the fund. ${ }^{5}$ In practice, however, the investment management company decides to create a new fund, assigns a fund manager to the fund, and then selects a board of directors to monitor the handling of the fund's assets. Throughout the rest of the paper, we will refer to an investment management company which offers more than one fund as a "mutual fund family." 
To state it in terms of the diversification literature, the mutual fund family corresponds to a corporation, the fund managers to business unit presidents, and the shares in individual funds to the products that the corporation offers.

\section{< FIGURE 1 ABOUT HERE >}

The investment management company itself is a publicly or privately held firm. As a result, fund managers not only have a fiduciary duty vis-à-vis fund shareholders but are also financially accountable to the owners of the investment management company. Thus, an agency problem can arise, since the incentives of the fund family owners are not necessarily congruent with the interests of the fund shareholders. Recent research has started to explore empirically these potentially divergent interests. For instance, Tufano and Sevick (1997) find that the composition of the fund board affects the level of fees investment management companies charge funds for providing their services, while Chevalier and Ellison (1997) find that fund managers increase the riskiness of their fund portfolios in the later months of the year if they have experienced low performance early in the year. ${ }^{6}$

\section{$\underline{\text { II.2. Possible sources of a focus effect }}$}

What are potential sources of a focus effect in the mutual fund industry? In particular, what effects could focus have on fund performance (an internal "production" effect) and on cash inflows (an external "demand" effect)? We will consider the production effect first. 
One possible way for family focus to influence fund performance is via the alignment of investment styles and fund types. The investment and research styles that guide the selection of securities for a mutual fund portfolio fall into very different categories, e.g., fundamental investing and investing using quantitative analysis. While the former involves in-depth analysis of each individual security the fund manager decides to invest in, the latter involves strict quantitative, often computerized, screening and analysis of security prices. Each family acquires a distinctive investment style that permeates the entire institution. ${ }^{7}$ For instance, Fidelity is imbued with a fundamental investment style, as it has been preached and practiced by Edward Johnson II, Fidelity's owner and CEO, and by Peter Lynch, Fidelity's most prominent former fund manager. Each style, in turn, has many ramifications for how investment analysis is conducted, how performance is evaluated, and how internal reputations are created.

The investment culture within a fund family can influence the focus-profitability relationship, because different types of funds can warrant different investment styles. A family offering a broad array of diverse funds may encounter difficulties either because investment styles and fund characteristics match poorly, or because the family tries to accommodate different styles within the same investment management company. For instance, Fidelity has established itself as a "playground" for equity managers. Fundamental research is encouraged, and fund managers pride themselves on being able to find good bargains and to trade quickly in order to earn higher returns than the market. It was these "gunslingers" who were held in highest esteem within the Fidelity hierarchy. As a result, Fidelity's bond fund managers tried to emulate this style. There was, however, much less room for this kind of investment style in the fixed-income arena, where in 
general low expenses, and not clever security selections, drive returns. The problems caused by this mismatch climaxed in 1994, when aggressive investing in the U.S. bond market and moves into risky derivatives and Latin American debt led to huge losses. A New York Times article covering this incidence concluded: "The Fidelity story also reveals some dirty little secrets that the mutual fund industry, busy selling Americans on the idea of one-stop shopping, would rather investors not know: the very things that make a company good at managing some kinds of investments may make them bad at running others" (Eaton 1995).

A further example of internal problems generated by frictions between different investment and research styles comes from a large Canadian mutual fund provider. ${ }^{8}$ Funds that invest mainly in blue-chip stocks and funds that invest in small-cap stocks differ greatly in the amount of additional analysis that a fund manager has to undertake. Bluechip stocks are already under such scrutiny by investment bank- and broker analysts that often very little additional analysis is required. On the other hand, for small-cap stock funds, fundamental analysis by the fund managers themselves, which might include road trips, is needed. In the case of this Canadian mutual fund family, the Director of Canadian Investments was managing a blue-chip stock fund and oversaw a small-cap stock fund. She could not understand the high expenses incurred from road trips of the small-cap stock fund managers and demanded that expenses be cut. As a result, research was hindered and returns suffered.

In Section IV, we will test for the internal effects of focus by analyzing the relationship between fund performance and the degree of fund family focus. 
While the internal effect of focus corresponds to returns to specialization in the "production" of particular types of mutual funds, the external, or demand, effect relates to possible benefits or detriments of focus in the marketplace. For instance, fund families that offer only a few categories of funds may have a clear corporate image in the minds of customers. They stand for particular types of funds, and whenever the need arises for investors to allocate assets to these types of funds, the investors know where to turn. Contrary to this, a family which offers a broad variety of funds may attract assets because investors might find it convenient to use only one fund family for all their investment needs. Clearly, there exist many factors besides focus that influence the purchase decisions of investors. As a result, our goal is not to explain consumer behavior. Rather, we explore whether one possible factor influencing the purchase decision, i.e., focus, has an impact on the cash inflows into fund families. Moreover, the main reason for studying the relationship between focus and total inflows into families is to reveal the incentives family owners face with respect to focus. Since costs of operating funds are fairly fixed and fund management fees are proportional to assets under management, a main concern of fund family owners is to increase fund inflows. ${ }^{9}$

\section{III.1. Different types of funds}

As discussed in the previous section, a fund family that focuses on particular fund categories is able to align its activities and to design its policies and organizational structure more appropriately than a family which offers a wide variety of funds. Thus, a

useful focus measure can be based on the various types of funds offered by a fund family. ${ }^{10}$ In general, funds fall into three categories: money market funds, equity funds, and bond 
funds. Since differences in investment styles are particularly acute among and between bond and equity funds, this study concentrates on these two types of funds.

We employ a classification scheme developed by Morningstar, one of the leading mutual fund rating agencies, which categorizes funds using the characteristics of the security portfolio held by the funds. For instance, a domestic equity fund is classified as "Large Value" if the mean market capitalization of the companies in its portfolio is greater than $\$ 5$ billion and the mean price-to-earnings ratio of the portfolio is significantly below the P/E ratio of the S\&P 500. Domestic bond funds are classified along the dimensions of average maturity and average risk rating (for exact definitions see Appendix 1). International funds are classified by the countries of which the fund is holding securities, e.g., "Japan fund." In total, there are 44 Morningstar categories (see Appendix 2). Please note that whenever the term "categories" is used in this paper, we are referring to these Morningstar categories. Since index funds alleviate the problems of misalignments as described in the previous section, we introduce a further "index fund" category for the sole purpose of computing focus measures (see next section). ${ }^{11}$ The performance of an index fund is still compared, however, to its peers as defined by its Morningstar category.

\section{III.2. Focus, performance, and flow measures}

Given the discussion in Section II.2 on internal focus effects, we would expect that funds which belong to focused families perform better than funds which belong to more diversified fund families. Moreover, we want to explore whether any potential focus effect is driven by "relatedness" or by "narrowness." We would receive evidence for a relatedness effect if we were to find that funds which belong to categories that a fund 
family is specializing in are performing better than funds which do not belong to such a category. Likewise, a negative effect of the breadth of product offering on fund performance would provide evidence of a narrowness effect. In other words, we want to distinguish between benefits for a fund that arise from being a fund in a family which offers many similar funds, and benefits for a fund that arise from being a fund in a family that offers funds in only a few categories (regardless of whether the fund belongs to a category the family specializes in).

Thus, in the first step, we will test for the effect of focus by analyzing the following relationship:

"fund performance" $=f$ ("family focus," other controls $)$

In the second step, we will attempt to shed light on the sources of a potential focus effect by exploring the relationship:

"fund performance" $=f$ ("narrowness measure," "relatedness measure," other controls)

Lastly, to explore the incentives of fund family owners with respect to focus, we will analyze the relationship between family focus and cash inflows into fund families:

"flows into fund families" $=f$ ("family focus," other controls)

In the following paragraphs, we will define more precisely the measures of family focus, relatedness, narrowness, fund performance, and cash inflows. 


\section{III.2.1. Measures of focus, relatedness, and narrowness}

We follow the diversification literature in employing a Herfindahl-like measure as an indicator of family focus. For family $k$ at time $t$ we define

$$
\text { focus }_{k t}=\sum_{j}\left(\frac{\text { assets of family } k \text { in category } j \text { at time } t}{\text { total assets of family } k \text { at time } t}\right)^{2}
$$

where the sum is taken over all categories $j$ of family $k$ at time $t$.

In our exploration of the sources of the focus effect, we want to include measures of relatedness and narrowness rather than an overall focus measure. For the relatedness measure, we construct a variable for each fund that measures the degree to which its fund family has focused on similar funds. Let fund $i$ be in category $j$ and a member of family $k$ at time $t$. Then variable related $_{i t}$ is defined as: assets of family $k$ in category $j$ at time $t$, divided by total assets of family $k$ at time $t$. One should note that this relatedness measure is not the same for all funds within a family (unless all the funds happen to be in the same category). Thus, this measure allows us to differentiate between funds that belong to a family's core group(s) and funds that are lone stragglers within a family.

As narrowness-of-strategy measure we use the number of categories a family is engaged in at time $t$ (variable narrow $_{k t}$ ). By including both related $d_{i t}$ and narrow s $_{k t}$ in the later performance regressions, we will be able to distinguish between a narrowness effect from which all funds within a family benefit, and a relatedness benefit, which accrues only to funds that belong to a core group of a family. 


\section{III.2.2. Measures of fund performance}

Since no single "perfect" performance measure for mutual funds exists—and for the sake of robustness-we construct four different performance measures. All measures have as their starting point the total annual return of each fund which includes dividends paid.

In order to make total returns comparable across funds, we adjust total returns to account for the fact that some funds charge a sales fee (called a "load"). ${ }^{12}$ We will refer to these returns as "adjusted total returns." Morningstar also reports the average returns for each of its 44 categories. These averages are computed over the entire population Morningstar tracks (in total over 7,500 funds, comprising essentially all industry participants).

For the first performance measure used in the analysis, we subtract from each fund's adjusted return the mean of its category. The resulting variable is called $d$ cret (difference from category return).

Second, since the total return is net of expenses charged to the fund, we measure the "gross return" achieved by a fund's security portfolio by adding the expense ratio to the total annual return. ${ }^{13}$ Subtracting from these gross returns the respective mean category performance and the mean category expense ratio yields variable dgret (difference in gross returns).

The third performance measure is based on "Jensen's alpha," which is derived from the standard capital asset pricing model (Jensen 1968). By this measure, the excess return of fund $i$ in period $t$ is given by:

$$
\text { alpha }_{i t}=\left(\mathrm{R}_{\mathrm{it}}-\mathrm{R}_{\mathrm{ft}}\right)-\beta_{\mathrm{i}}\left(\mathrm{R}_{\mathrm{mt}}-\mathrm{R}_{\mathrm{ft}}\right)
$$


where $\mathrm{R}_{\mathrm{it}}$ is the total return of fund $i, \mathrm{R}_{\mathrm{ft}}$ the risk-free rate (90-day $\mathrm{T}$-Bill), and $\mathrm{R}_{\mathrm{mt}}$ the return of an appropriate market benchmark.

The risk measure $\beta_{\mathrm{i}}$, in turn, is computed by running for each fund the standard CAPM regression: ${ }^{14}$

$$
\left(R_{i t}-R_{f t}\right)=\alpha_{i}+\beta_{i}\left(R_{m t}-R_{f t}\right)
$$

As Elton et al. (1993) point out, the choice of an appropriate market benchmark is crucial in the computation of Jensen's alpha (see below). Consequently, rather than assigning to each equity fund the S\&P 500 index as benchmark and to each bond fund a broad bond index, we assign to each category the index that is used by Morningstar to benchmark the performance of that particular category (see Appendix 2).

Lastly, the fourth performance variable, malpha, is an excess return measure which uses monthly performance data obtained from Morningstar's Principia Plus database. Whereas in the construction of alpha we implicitly assumed a constant $\beta_{\mathrm{i}}$ over time, we are now able to relax this assumption. The variable malpha is based on multi-index models suggested by Gruber (1996), and Blake, Elton, Gruber (1993). To understand the underlying idea of multi-index models, assume that over a period of time small-cap stocks outperform large-cap stocks. Then, using a total market index to compute beta would result in a positive alpha for a fund that held small-cap stocks. The question is, should we attribute this excess return to the skill of the fund manager, or not? In most cases, the choice to invest in small-cap stocks was not made by the fund manager, but the manager was charged to manage a small-cap stock fund. Hence, a more appropriate market benchmark for judging the manager's performance is a small-cap index. This is the rationale for matching funds to different market benchmarks in the computation of alpha 
above. To control for the fact that many funds invest in more than one type of security, Gruber (1996) suggests to regress the returns of funds on several indices and to compute a set of relevant betas. More precisely, for domestic equity funds we run the following regression: ${ }^{15}$

$$
\left(\mathrm{R}_{\mathrm{it}}-\mathrm{R}_{\mathrm{ft}}\right)=\alpha_{\mathrm{i}}+\beta_{1 \mathrm{i}}\left(\mathrm{R}_{\mathrm{mt}}-\mathrm{R}_{\mathrm{ft}}\right)+\beta_{2 \mathrm{i}}\left(\mathrm{R}_{\mathrm{st}}-\mathrm{R}_{\mathrm{lt}}\right)+\beta_{3 \mathrm{i}}\left(\mathrm{R}_{\mathrm{gt}}-\mathrm{R}_{\mathrm{vt}}\right)+\beta_{4 \mathrm{i}}\left(\mathrm{R}_{\mathrm{dt}}-\mathrm{R}_{\mathrm{ft}}\right)
$$

where $\quad \mathrm{R}_{\mathrm{it}}=$ the return of fund $i$ in month $t$

$\mathrm{R}_{\mathrm{ft}}=$ the 30-day T-Bill rate in month $t$

$\mathrm{R}_{\mathrm{mt}}=$ the return on the $\mathrm{S} \& \mathrm{P} 500$ index in month $t$

$\mathrm{R}_{\mathrm{st}}=$ the return on a small-cap portfolio in month $t$ (average return on the Wilshire Small Cap Index and the Wilshire Small Value Index)

$\mathrm{R}_{\mathrm{lt}}=$ the return on a large-cap portfolio in month $t$ (average return on the Wilshire Large Cap Index and the Wilshire Large Value Index)

$\mathrm{R}_{\mathrm{gt}}=$ the return on a growth portfolio in month $t$ (average return on the Wilshire Small Cap, Mid Cap, and Large Cap Growth Indices)

$\mathrm{R}_{\mathrm{vt}}=$ the return on a value portfolio in month $t$ (average return on the Wilshire Small Cap, Mid Cap, and Large Cap Value Indices)

$\mathrm{R}_{\mathrm{dt}}=$ the return on the Lehman Brothers (LB) Aggregate Bond Index in month $t$

We then compute our new excess return measure as

malpha $_{i t}=\left(\mathrm{R}_{\mathrm{it}}-\mathrm{R}_{\mathrm{ft}}\right)-\beta_{\mathrm{li}}\left(\mathrm{R}_{\mathrm{mt}}-\mathrm{R}_{\mathrm{ft}}\right)-\beta_{2 \mathrm{i}}\left(\mathrm{R}_{\mathrm{st}}-\mathrm{R}_{\mathrm{lt}}\right)-\beta_{3 \mathrm{i}}\left(\mathrm{R}_{\mathrm{gt}}-\mathrm{R}_{\mathrm{vt}}\right)-\beta_{4 \mathrm{i}}\left(\mathrm{R}_{\mathrm{dt}}-\mathrm{R}_{\mathrm{ft}}\right)$

To take into account that betas might change over time, regression (3) is run using three years of (rolling) monthly performance data. Thus, to obtain malpha for fund $i$ in month $t$, we use the performance of fund $i$ in the 35 months prior to and including month $t$ to find $\beta_{1 \mathrm{i}}, \ldots, \beta_{4 \mathrm{i}}$ from (3). These betas are then used in (4) to compute malpha for month $t$. Lastly, the malpha's are annualized over each calendar year.

For domestic bond funds, we employ a six-index model suggested by Blake, Elton, and Gruber (1993): 


$$
\begin{aligned}
\left(\mathrm{R}_{\mathrm{it}}-\mathrm{R}_{\mathrm{ft}}\right)=\alpha_{\mathrm{i}}+\beta_{1 \mathrm{i}}\left(\mathrm{R}_{\mathrm{gt}}-\mathrm{R}_{\mathrm{ft}}\right) & +\beta_{2 \mathrm{i}}\left(\mathrm{R}_{\mathrm{lgt}}-\mathrm{R}_{\mathrm{ft}}\right)+\beta_{3 \mathrm{i}}\left(\mathrm{R}_{\mathrm{ct}}-\mathrm{R}_{\mathrm{ft}}\right) \\
& +\beta_{4 \mathrm{i}}\left(\mathrm{R}_{\mathrm{lct}}-\mathrm{R}_{\mathrm{ft}}\right)+\beta_{5 \mathrm{i}}\left(\mathrm{R}_{\mathrm{mot}}-\mathrm{R}_{\mathrm{ft}}\right)+\beta_{6 \mathrm{i}}\left(\mathrm{R}_{\mathrm{hyt}}-\mathrm{R}_{\mathrm{ft}}\right)
\end{aligned}
$$

where $\quad \mathrm{R}_{\mathrm{it}}=$ the return of fund $i$ in month $t$

$\mathrm{R}_{\mathrm{ft}}=$ the 30-day T-Bill rate in month $t$

$\mathrm{R}_{\mathrm{gt}}=$ the return on the LB Intermediate-Term Government Bond Index in month $t$

$\mathrm{R}_{\mathrm{lgt}}=$ the return on the LB Long-Term Government Bond Index in month $t$

$\mathrm{R}_{\mathrm{ct}}=$ the return on the LB Intermediate-Term Corporate Bond Index in month $t$

$\mathrm{R}_{\mathrm{lct}}=$ the return on the LB Long-Term Corporate Bond Index in month $t$

$\mathrm{R}_{\mathrm{mot}}=$ the return on the LB Mortgage Backed Bond Index in month $t$

$\mathrm{R}_{\text {hyt }}=$ the return on the First Boston High Yield Bond Index in month $t$

We then compute our new excess return measure for bond funds as

$$
\begin{aligned}
\text { malpha }_{i t}=\left(\mathrm{R}_{\mathrm{it}}-\mathrm{R}_{\mathrm{ft}}\right) & -\beta_{1 \mathrm{i}}\left(\mathrm{R}_{\mathrm{gt}}-\mathrm{R}_{\mathrm{ft}}\right)-\beta_{2 \mathrm{i}}\left(\mathrm{R}_{\mathrm{lgt}}-\mathrm{R}_{\mathrm{ft}}\right)-\beta_{3 \mathrm{i}}\left(\mathrm{R}_{\mathrm{ct}}-\mathrm{R}_{\mathrm{ft}}\right) \\
& -\beta_{4 \mathrm{i}}\left(\mathrm{R}_{\mathrm{lct}}-\mathrm{R}_{\mathrm{ft}}\right)-\beta_{5 \mathrm{i}}\left(\mathrm{R}_{\mathrm{mot}}-\mathrm{R}_{\mathrm{ft}}\right)-\beta_{6 \mathrm{i}}\left(\mathrm{R}_{\mathrm{hyt}}-\mathrm{R}_{\mathrm{ft}}\right)
\end{aligned}
$$

Lastly, we need a measure of cash flows into each fund family. Cash flows at the level of the fund can be estimated by the difference in fund size after adjusting for appreciation (or depreciation) of the existing asset stock. Cash flows at the level of the family are then obtained by summing over all funds within one family:

$$
\text { famflow }_{k t}=\sum_{\text {netass }_{i t}}-\left(1+\text { totret }_{i t}\right) \text { netass }_{i(t-1)}
$$

where netass $_{i t}$ are the total assets of fund $i$ at the end of year $t$, totret $_{i t}$ is the total return of fund $i$ in year $t$, and the sum is taken over all funds $i$ within family $k$.

\section{III.3. Data and methods}

Data was collected on all bond and equity funds covered by Morningstar in its Morningstar Mutual Funds publication as of December 1996. The database consists of a 
growing number of funds, starting in December 1985 with 568 funds and ending in December 1996 with 1,404 funds offered by 206 families. Out of these 1,404 funds, 962 are equity funds and 442 bond funds. These 1,404 funds held a total of $\$ 1,745$ billion in assets which constituted about 77\% of all assets in bond and equity funds in 1996 . Over the years, the sample covers $75-94 \%$ of all assets in equity funds and $46-75 \%$ of all assets in bond funds. In general, coverage declines over the period of the sample.

To alleviate a possible sample selection bias (see also Section IV.2) and to be able to distinguish between the relatedness and the narrowness effects, funds are only included in the analysis if their families offer at least two funds; this reduces the sample slightly, e.g., in 1996 to 1,349 funds with $\$ 1,718$ billion in assets.

Since our data is in the form of a panel, an econometric procedure that utilizes this structure seems to be warranted. Panel estimation-techniques require more or less restrictive assumptions on the within-group correlation structure. (In the present case all observations for each fund correspond to a group.) Let $\mathbf{R}$ be the correlation matrix for modeling the within-group correlation. Let $R_{t, s}$ denote the $t$, s element. The technique employed in the next section imposes as only constraint on the correlation matrix that the diagonal elements be equal to 1 and the matrix be symmetric, i.e., $R_{t, s}=1$ if $t=s$, and $\rho_{t s}$ otherwise, with $\rho_{\mathrm{ts}}=\rho_{\mathrm{st} .}{ }^{16}$ Hence, we take into account possible autocorrelation between observations over time without having to specify a particular autocorrelation structure (Liang and Zeger 1986). To further account for possible heteroscedasticity across groups, we use the Huber (1967), White (1980) robust estimator of variance. 


\section{$\underline{\text { IV.1. Relationship between performance and focus }}$}

In exploring the effect of family focus on fund performance, we will proceed in two steps. In the first step, following the diversification literature, we will test whether overall family focus has an impact on fund performance. In the second step, we will analyze whether it is relatedness or narrowness which drives the focus effect. Studies which have tested whether funds outperform passive market indices suggest to include variables which control for differences in (portfolio) turnover, expense ratio, sales loads, and fund size. Accordingly, we include variables diffturn, which measures the difference between a fund's turnover and the average turnover of its category, variable diffexpense, which measures the difference between a fund's expense ratio and the average expense ratio of its category, and variable loaddum, a dummy equal to one if the fund charged a front- or a back-end load. Since the measures of focus and relatedness both involve non-linear size terms, we include a fairly flexible size specification in our model to avoid misspecification. As a result, rather than including, for instance, the logarithm of size, which would force upon the estimation decreasing (or increasing) returns over the entire range of values, we include linear, quadratic, and cubic terms of fund- and family size.

Further variables at the level of the fund include the age and the square of the age of the fund, the market share of the fund within its category, and the standard deviation of its monthly returns over the year. Given potential sample selection bias in the data (see discussion in Section IV.2), we would expect a negative coefficient on the linear age term. The fund's market share was included, because on one hand a manager with a large share within a category might receive preferential treatment by industry analysts, while on the 
other hand the manager might find it increasingly more difficult to find attractive securities.

Further control variables at the level of the family include the sum of assets of the family within the category and the number of funds of the family within the category (of the particular fund). Families which have large categories might be able to avoid the problems of misalignment as discussed in Section II.2.

Lastly, we include the number of funds that exist in the category as a measure of general competition, for instance, for mis-priced securities. ${ }^{17}$

Thus, our regression model is specified as follows:

Performance of fund $i$ belonging to family $k$ and category $j$ at time $t=$ constant

$$
\begin{aligned}
& +\alpha_{1} \text { focus }[\mathrm{t}-1] \quad \text { Herfindahl index of family } k \\
& +\alpha_{2} \text { diffturnover [t] (turnover of } i \text { ) - (mean turnover of category } j \text { ) } \\
& +\alpha_{3} \text { diffexpense [t] (expense ratio of } i \text { ) }- \text { (mean expense ratio of cat. } j \text { ) } \\
& +\alpha_{4} \text { loaddum }[\mathrm{t}] \quad \text { dummy }=1 \text { when } i \text { had a load in } 1996 \\
& +\alpha_{5} \text { age }[\mathrm{t}] \quad \text { age of fund } i \\
& +\alpha_{6} \operatorname{age}^{2}[\mathrm{t}] \quad \text { square of fund } i \text { 's age } \\
& +\alpha_{7} \text { assets }[\mathrm{t}-1] \quad \text { net assets of fund } i \\
& +\alpha_{8} \operatorname{assets}^{2}[\mathrm{t}-1] \quad \text { squared net assets of fund } i \\
& +\alpha_{9} \operatorname{assets}^{3}[\mathrm{t}-1] \quad \text { cubed net assets of fund } i \\
& +\alpha_{10} \text { fund mshare }[\mathrm{t}-1] \quad \text { market share of fund } i \text { in category } j \\
& +\alpha_{11} s t d v[\mathrm{t}] \quad \operatorname{stdv} \text { of fund } i \text { 's monthly returns over year } t \\
& +\alpha_{12} \text { family assets }[\mathrm{t}-1] \quad \text { net assets of family } k
\end{aligned}
$$

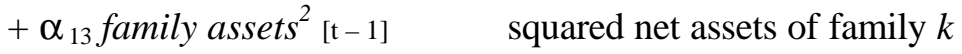

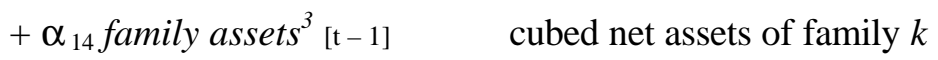

$$
\begin{aligned}
& \left.+\alpha_{15} \text { family assets in cat [t }-1\right] \quad \text { sum of assets of family } k \text { in category } j \\
& \left.+\alpha_{16} \text { family funds in cat [t }-1\right] \text { number of funds of family } k \text { in category } j \\
& +\alpha_{17} \text { funds in cat }[\mathrm{t}] \quad \text { total number of funds in category } j
\end{aligned}
$$

where $[\mathrm{t}]$ means the variable is taken at the end of year $t$, and $[\mathrm{t}-1]$ that the variable is taken at the end of year $t-1$. 
For results, see Table 1. The dependent variable in regression (1) is dcret, the difference between the fund's adjusted total returns and the average adjusted total returns of its category. In regressions (2) - (4) we use dgret, alpha, and malpha as performance measures. In all four regressions the (lagged) focus variable is positive and highly significant. The p-value for the coefficient on the focus variable across the regressions is $0.006,0.012,0.027$, and 0.002 , respectively. The effect is not only statistically significant, but economically relevant as well. Comparing families at the $20^{\text {th }}$ and $80^{\text {th }}$ percentile of the focus measure, the coefficients imply a size of the effect of 43, 40, 61, and 59 basis points per year.

\section{$<$ TABLE 1 ABOUT HERE >}

Due to space constraints and our primary concern with the focus variable, we will discuss the coefficients of the control variables only briefly. Turnover appears to have a neutral effect on fund performance, while we find some evidence that higher expenses decrease performance. The variable diffexpense is negative and strongly significant in regression (4) and significantly less than one in regression (2). Recall that variable $d g r e t$ increases one-to-one with the expense ratio. Thus, a coefficient less than 1 on the diffexpense variable in regression (2) implies that net performance suffers when expenses are increased.

For the interpretation of the coefficient on the load dummy, we need to recall that dcret is adjusted for sales loads, while the other three performance measures are not. The 
general result is that the performance of funds (taking loads into account) is negatively affected by sales loads. ${ }^{18}$

The market share of a fund appears to have a negative effect on performance. Using the coefficient from regression (1) and comparing funds at the $20^{\text {th }}$ and $80^{\text {th }}$ percentile of fund mshare, the effect is about 25 basis points.

Lastly we note that at least for regressions (3) and (4) there is a negative impact of the number of funds within the category on fund performance.

Having documented the existence of a focus effect on fund performance, we will now turn to the question of the sources of this focus effect. Is the focus effect driven by relatedness or by narrowness? To provide an answer, we will use the above regression model but replace the focus variable with the related and the narrow variables. Results of this regression model can be found in Table 2. Again, for the sake of robustness, we use all four different performance measures as independent variables.

\section{<TABLE 2 ABOUT HERE >}

The measure of relatedness is positive in all four regressions and significant at the $1 \%$ level in regression (3), at the 5\% level in regressions (1) and (2), and at the $10 \%$ level in regression (4). In contrast, the measure of narrowness is insignificant in all four regressions. Thus, the benefit of focus appears to accrue only to funds that belong to a category of funds the fund family is concentrating on. Mere membership in a focused family does not generate a performance benefit for a fund. 
What is the magnitude of the relatedness effect? Comparing two funds at the $20^{\text {th }}$ and $80^{\text {th }}$ percentile of related in 1996 , the effect is, depending on the performance measure, 30 , 27, 62, and 25 basis points per year.

One objection to the results between performance and family focus could involve the possible reverse direction of causality. Perhaps fund families which have poorly performing funds start to diversify. There exists some evidence in the finance and industrial organization literature that poorly performing firms start to diversify broadly (Morck, Shleifer, and Vishny 1990, Lang and Stulz 1994) and that low-value mergers are more likely to be undertaken by firms with poor prospects for increasing their profit streams from their existing activities (You et al. 1986). To determine whether fund families which perform poorly start to increase their product portfolio, we construct a new variable, $\Delta$ focus $_{k t}$, which measures the change in focus of family $k$ between years $t$ and $t-$ 1 , and regress it on various past average performance measures of families, controlling for family size, average fund age, average flows into categories, and average expense levels (see Section V. for definitions of variables at the family level). For all performance measures the coefficient on the past performance variable is insignificant, thus throwing doubt on the reverse-causality explanation in this case (detailed results available from the author).

\section{IV.2. Sample selection bias}

We need to be concerned about the following possible sample selection bias: Morningstar may cover in its publication only those small families (and funds) which are successful. Since there exists a negative correlation between focus and family size, the 
focus measure could pick up a size effect caused by the selection bias. Similarly, small families might be covered less completely than large families. If only hot performing funds of small families are covered, it could again induce a negative relationship between family size and performance.

To alleviate this selection bias problem, linear and non-linear terms for both the size of the fund and the size of the family are included in the performance regressions. An age variable, which presumably picks up some of the selection bias effect as well, is also included. Moreover, since lagged variables are used in the regression, the performance in the first year of each new fund is excluded. Thus, first-year blips in performance, which could have caused Morningstar to cover a fund, do not influence the results. In addition, once Morningstar begins to cover a fund, it is not dropped very quickly.

Lastly, we exclude from the analysis all families that have only one fund (in year $t$ ). Clearly, for these funds the focus measure would be equal to 1 , yet the inclusion of these funds could be driven by high past performance. We would potentially detect a very strong focus effect for these funds (which truly might exist), but which might be overstated since we do not include all other one-fund families with similarly high focus.

To see whether there exists a strong small family-size or fund-size effect in the data, we compute the unconditional correlation coefficients between the four performance variables and family- and fund size. While the correlation coefficients between fund size and the performance measures are insignificant, the correlation coefficients between family size and the performance measures are (weakly) significant. However, the correlation is positive, i.e., the reverse of what we would expect in the presence of a strong sample bias of the kind described above. ${ }^{19}$ 


\section{$\underline{V}$. The impact of focus on cash inflows at the family level}

In the last section, we found that funds belonging to families which are focused have higher returns, ceteris paribus, than funds belonging to broadly diversified families. Given the intuitive - and empirically validated-positive relationship between past performance and inflows at the fund level (e.g., Chevalier and Ellison 1997, Sirri and Tufano 1998) and the fact that fund families' payoffs are proportional to fund inflows, the question arises why are all fund families not highly focused? To answer this question, we should note that even though owners of fund families care about inflows into individual funds, they are ultimately concerned with the total flows into all funds they are offering. Thus, to gauge the incentives of family owners with respect to focus, we need to analyze how focus affects total inflows into fund families.

With the help of the above-cited studies of the relationship between performance and inflows at the fund level, we identify several relevant control variables. First of all, we control for the size of the family. To allow for potential non-linearities we again include

linear, square, and cubic terms of the lagged net assets of the family. ${ }^{20}$ Second, we control for the past performance of the funds in each family. For sake of robustness, we employ several average performance measures. Whenever we average at the family level, we weight by individual fund asset size. The first performance measure is the average of $d c r e t$. The second performance measure is the average of malpha. A third and fourth performance measure are the percentile ranks of each fund, where each fund was ranked within its category using either adjusted total returns or malpha. These ranks were then averaged over all funds within each family. 
Following Sirri and Tufano (1998), who show that prior performance does not have a linear effect on cash flows into individual funds, we include in some regressions not a single family performance measure but rather piecewise ranks as defined by:

$$
\begin{aligned}
& \text { average low performance }_{k t}=\operatorname{Min}\left(\operatorname{Rank}_{k t}, 0.2\right) \\
& \text { average medium performance }_{k t}=\operatorname{Min}\left(0.6, \text { Rank }_{k t}-\text { average low performance }_{k t}\right) \\
& \text { average high performance }_{k t}=\text { Rank }_{k t}-\left(\text { average low performance }_{k t}+\text { average }^{\text {medium performance }} \text { prt }_{t}\right)
\end{aligned}
$$

where $\operatorname{Rank}_{k t}$ is the asset-weighted average of the percentile ranks of all funds within family $k$ in year $t$ and ranking for each fund is conducted within the fund's respective category using either adjusted total returns or malpha.

These piecewise linear regressors pick up the relationship between flows and past performance, contingent upon whether the family's overall performance (as compared to all other families) fell in the lowest quintile, in the middle $60 \%$, or in the upper quintile. In other words, these regressors allow us to estimate three different slope parameters for the past-performance-flow relationship, depending on how well the family performed in the previous year.

Next, we control for the average age of funds within each family. Again, there might be a non-linear relationship, because new funds might receive a lot of marketing support while very old funds have reputation effects which could help increase inflows. We further control for the expenses charged, by including an average of the variable diffexpense. To control for a potential dislike of investors for volatility, we include the average of the funds' standard deviation of monthly returns. 
We include two further control variables which measure industry-wide effects. We compute the total flows into each category, and weight the flows for each family by the percentage of assets that the family has in each category. Thus, we control for sector flows into particular categories, which may have been en vogue in a particular year. Secondly, to assess how many competitors the funds of a family face within their categories, we multiply the number of funds in each category by the percentage of assets that the family has in each category.

There are possibly other family-specific variables which could influence the total cash inflows into families, such as the amount spent on advertising. Unfortunately, such data is difficult to obtain for the 151 families which we track over 13 years. To take into account family-specific differences, we employ a fixed-effect regression model which controls for (constant) family differences.

Thus, the regression we run is specified as follows:

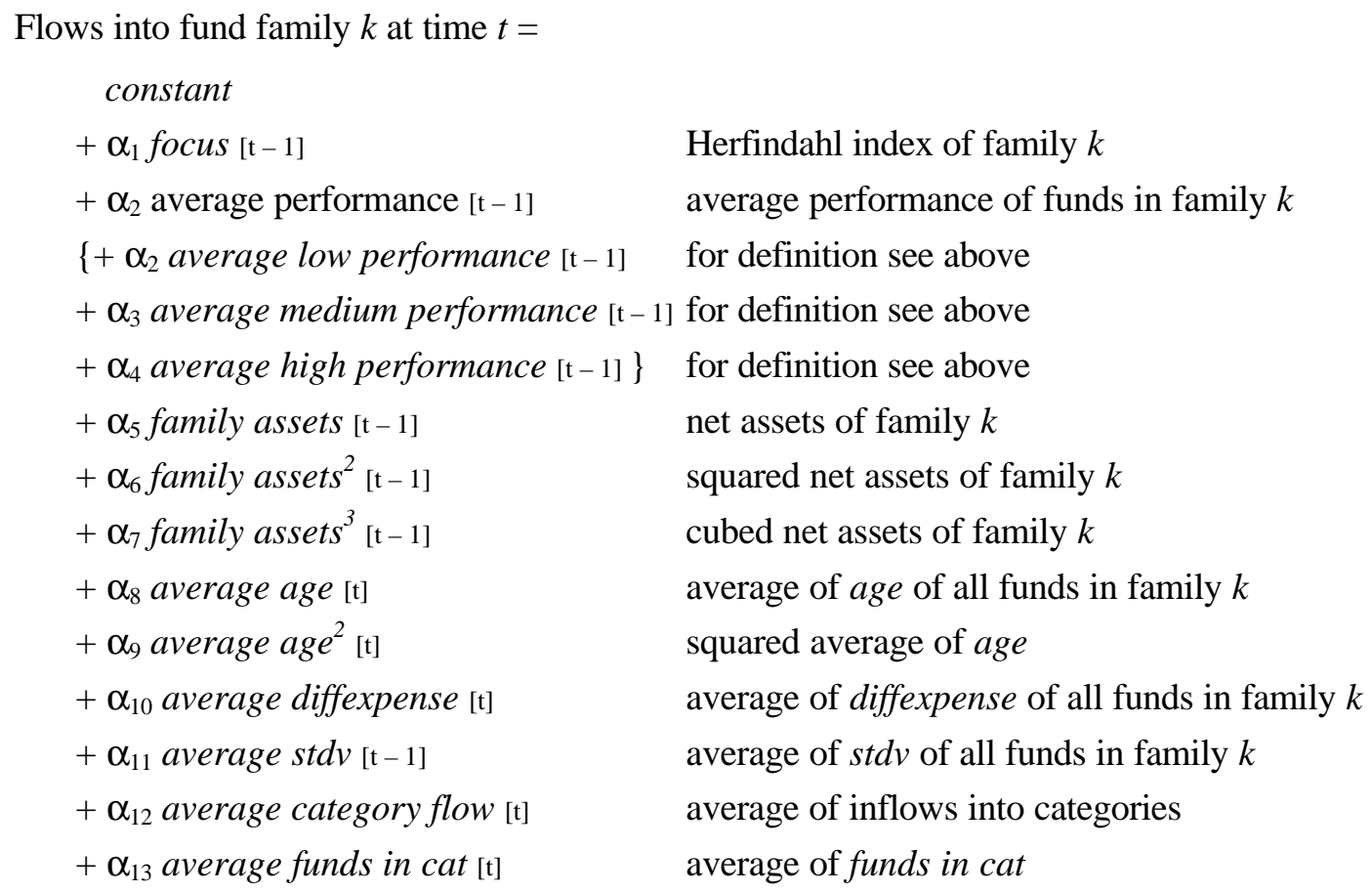


where we include either a single linear past performance measure or three piece-wise linear past performance regressors, and all averages are asset-weighted.

For results of the cash flow regressions, see Table 3. Regressions (1) - (6) differ in the way we control for past performance. In regression (1) the average past performance measure is based on dcret, in regression (2) the measure is based on malpha, in regressions (3) and (4) the measures are based on ranking using adjusted total returns, and in regressions (5) and (6) the measures are based on ranking using malpha.

Across all six regressions we observe a negative and significant effect of family focus on cash inflows into families. Moreover, the effect is substantial. Comparing two families with a focus measure one standard deviation apart, regression (1), for instance, suggests an effect of about \$263 million more inflow for the less focused family—a large effect, given that the mean inflow into families is $\$ 478$ million. Thus, the owners of fund families face strong incentives to increase the breadth of their product offering.

\section{<TABLE 3 ABOUT HERE>}

Given the results between individual fund performance and family focus, one may point out that higher focus leads to better fund performance, which in turn should increase inflows. To test the size of this indirect effect, we drop the past performance control variable in regression (7), thereby attributing the positive externality of focus (on flows) onto the focus measure. As can be seen in Table 3, the coefficient on the focus measure remains basically unchanged. Thus, at the family level, the indirect negative effect of diversification on cash inflows via reduced fund performance is only very small. 
Using linear past performance measures, we see a positive, yet insignificant, relationship between past family-wide performance and consequent cash inflow. The piece-wise linear regressors allow us to paint a more differentiated picture. Similar to the findings of Chevalier and Ellison (1997) and Sirri and Tufano (1998) at the fund level, we find that at the family level, performance differences among very poor performing families do not affect inflows. The surprising result is that among very well performing families performance differences do not appear to affect inflows either. Only in the intermediate range do performance differences play a role.

While the sector flows have a significant impact on inflows into families, differences in expenses, volatility, and number of funds in the category do not affect inflows significantly. Lastly, families with many young funds appear to gain extra inflows.

\section{$\underline{\text { VI. Conclusion }}$}

This paper set out to analyze the effects of focus in an intra-industry setting. While benefits of focus have been previously documented at the inter-industry level, the effects of focus at the intra-industry level have not found much attention. Moreover, we attempted to disentangle two different drivers of the focus effect: one based on relatedness and one based on narrowness.

We find that the performance of a mutual fund improves with overall family focus, and in particular with the fund family's degree of focus on that fund's category. Mere narrowness does not suffice: funds that belong to focused families, yet are lone stragglers, do not benefit with respect to performance from their membership in a focused family. Thus, for the internal benefit of focus, relatedness matters. One explanation that is 
consistent with these results, and consistent with field observations, is based upon fit within a firm's system of choices. A focused fund family is able to configure its activities, to design its organizational structure, and to assemble its resources more appropriately than a family that offers a broad array of different funds.

With respect to inflows into fund families - a measure of particular interest to fund family owners - we observe a negative effect of focus. The finding that family focus affects performance positively while reducing total inflows points towards a divergence of interests between the owners of fund families and fund shareholders. Since higher fund performance accrues to fund shareholders, shareholders would benefit from focused families. On the other hand, the owners of fund families, who profit from larger inflows, have an incentive to broaden a family's offering. This finding resonates with research examining the effects of direct marketing charges (12b-1 fees) levied by funds. Fund managers argue that the additional business generated by advertising yields scale economies which ultimately benefit the existing fund shareholders. Empirical research, however, indicates that these charges are a dead-weight cost borne by shareholders, i.e., do not benefit existing shareholders (e.g., Ferris and Chance 1987).

In sum, we find that fund shareholders and the owners of fund families may arrive at opposing answers to the question whether to focus. The results of the performance regressions indicate that housing different production technologies within the same organization can be difficult and lead to inferior product output. At the same time, in an environment in which size confers profitability, and where focus restricts size, focus can be detrimental from the point of view of the firm's owners. 


\section{Figure 1: Organization of Mutual Fund Families}

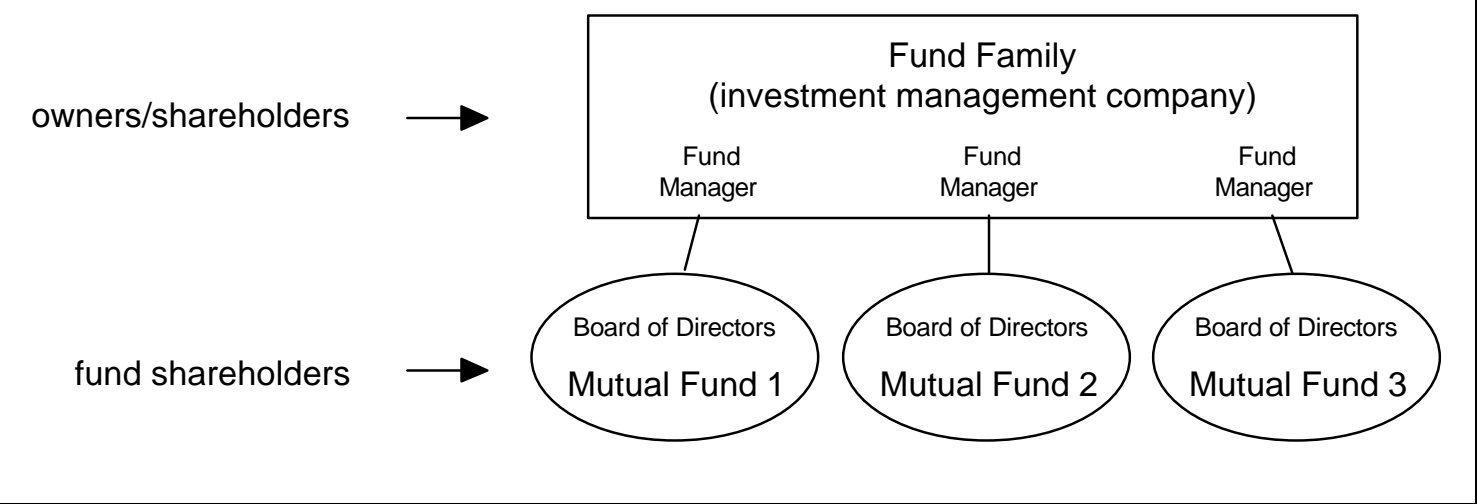


Table 1: The effect of family focus on fund performance ( $t$-values below coefficients)

\begin{tabular}{|c|c|c|c|c|}
\hline performance measure & $\begin{array}{r}(1) \\
\text { dcret }\end{array}$ & $\begin{array}{r}(2) \\
\text { dgret }\end{array}$ & $\begin{array}{r}(3) \\
\text { alpha }\end{array}$ & $\begin{array}{r}(4) \\
\text { malpha }\end{array}$ \\
\hline focus & $\begin{array}{r}1.356 \\
2.742\end{array}$ & $\begin{array}{r}1.233 \\
2.503\end{array}$ & $\begin{array}{r}1.906 \\
2.216\end{array}$ & $\begin{array}{r}1.841 \\
3.081\end{array}$ \\
\hline diffturn & $\begin{array}{r}0.002 \\
1.855\end{array}$ & $\begin{array}{r}0.002 \\
1.984\end{array}$ & $\begin{array}{r}0.000 \\
0.106\end{array}$ & $\begin{array}{r}0.002 \\
1.667\end{array}$ \\
\hline diffexpense & $\begin{array}{r}-0.020 \\
-0.089\end{array}$ & $\begin{array}{r}0.774 \\
3.428\end{array}$ & $\begin{array}{r}-0.476 \\
-1.200\end{array}$ & $\begin{array}{r}-1.149 \\
-4.048\end{array}$ \\
\hline loaddum & $\begin{array}{r}-0.705 \\
-4.935\end{array}$ & $\begin{array}{r}-0.062 \\
-0.435\end{array}$ & $\begin{array}{r}0.576 \\
2.346\end{array}$ & $\begin{array}{r}-0.115 \\
-0.659\end{array}$ \\
\hline age & $\begin{array}{r}-0.030 \\
-1.708\end{array}$ & $\begin{array}{r}-0.028 \\
-1.603\end{array}$ & $\begin{array}{r}-0.093 \\
-2.785\end{array}$ & $\begin{array}{r}-0.108 \\
-6.140\end{array}$ \\
\hline $\operatorname{age}^{2}$ & $\begin{array}{r}3.528 \mathrm{E}-04 \\
1.275\end{array}$ & $\begin{array}{r}3.159 \mathrm{E}-04 \\
1.138\end{array}$ & $\begin{array}{r}8.991 \mathrm{E}-04 \\
1.876\end{array}$ & $\begin{array}{r}1.267 \mathrm{E}-03 \\
4.708\end{array}$ \\
\hline assets & $\begin{array}{r}-1.356 \mathrm{E}-04 \\
-1.427\end{array}$ & $\begin{array}{r}-1.360 \mathrm{E}-04 \\
-1.440\end{array}$ & $\begin{array}{r}-6.150 \mathrm{E}-04 \\
-3.762\end{array}$ & $\begin{array}{r}-4.001 \mathrm{E}-04 \\
-3.456\end{array}$ \\
\hline assets $^{2}$ & $\begin{array}{r}2.750 \mathrm{E}-08 \\
3.642\end{array}$ & $\begin{array}{r}2.760 \mathrm{E}-08 \\
3.711\end{array}$ & $\begin{array}{r}5.410 \mathrm{E}-08 \\
3.527\end{array}$ & $\begin{array}{r}3.910 \mathrm{E}-08 \\
3.706\end{array}$ \\
\hline assets $^{3}$ & $\begin{array}{r}-4.950 \mathrm{E}-13 \\
-4.171\end{array}$ & $\begin{array}{r}-4.990 \mathrm{E}-13 \\
-4.277\end{array}$ & $\begin{array}{r}-8.280 \mathrm{E}-13 \\
-3.282\end{array}$ & $\begin{array}{r}-6.140 \mathrm{E}-13 \\
-3.642\end{array}$ \\
\hline fund mshare & $\begin{array}{r}-6.776 \\
-5.457\end{array}$ & $\begin{array}{r}-6.741 \\
-5.384\end{array}$ & $\begin{array}{r}-2.753 \\
-1.642\end{array}$ & $\begin{array}{r}-3.764 \\
-2.920\end{array}$ \\
\hline stdv & $\begin{array}{r}0.225 \\
2.889\end{array}$ & $\begin{array}{r}0.231 \\
2.915\end{array}$ & $\begin{array}{r}0.340 \\
3.685\end{array}$ & $\begin{array}{r}0.250 \\
3.816\end{array}$ \\
\hline family assets & $\begin{array}{r}2.540 \mathrm{E}-05 \\
2.243\end{array}$ & $\begin{array}{r}2.450 \mathrm{E}-05 \\
2.158\end{array}$ & $\begin{array}{r}3.400 \mathrm{E}-05 \\
1.666\end{array}$ & $\begin{array}{r}3.080 \mathrm{E}-05 \\
2.444\end{array}$ \\
\hline family assets ${ }^{2}$ & $\begin{array}{r}-1.170 \mathrm{E}-10 \\
-0.967\end{array}$ & $\begin{array}{r}-1.130 \mathrm{E}-10 \\
-0.937\end{array}$ & $\begin{array}{r}2.690 \mathrm{E}-11 \\
0.146\end{array}$ & $\begin{array}{r}-2.840 \mathrm{E}-10 \\
-2.135\end{array}$ \\
\hline family assets ${ }^{3}$ & $\begin{array}{r}1.380 \mathrm{E}-16 \\
0.421\end{array}$ & $\begin{array}{r}1.340 \mathrm{E}-16 \\
0.407\end{array}$ & $\begin{array}{r}-5.670 \mathrm{E}-16 \\
-1.216\end{array}$ & $\begin{array}{r}6.990 \mathrm{E}-16 \\
1.952\end{array}$ \\
\hline family assets in cat & $\begin{array}{r}-9.250 \mathrm{E}-07 \\
-0.039\end{array}$ & $\begin{array}{r}-6.190 \mathrm{E}-07 \\
-0.026\end{array}$ & $\begin{array}{r}-4.570 \mathrm{E}-05 \\
-0.933\end{array}$ & $\begin{array}{r}-8.640 \mathrm{E}-06 \\
-0.332\end{array}$ \\
\hline family funds in cat & $\begin{array}{r}-0.040 \\
-0.966\end{array}$ & $\begin{array}{r}-0.044 \\
-1.076\end{array}$ & $\begin{array}{r}0.117 \\
1.541\end{array}$ & $\begin{array}{r}0.005 \\
0.100\end{array}$ \\
\hline funds in cat & $\begin{array}{r}4.235 \mathrm{E}-04 \\
1.308\end{array}$ & $\begin{array}{r}3.312 \mathrm{E}-04 \\
1.023\end{array}$ & $\begin{array}{r}-3.444 \mathrm{E}-03 \\
-6.577\end{array}$ & $\begin{array}{r}-2.506 \mathrm{E}-03 \\
-6.962\end{array}$ \\
\hline constant & $\begin{array}{r}-0.016 \\
-0.051\end{array}$ & $\begin{array}{r}-0.031 \\
-0.099\end{array}$ & $\begin{array}{r}0.395 \\
0.722\end{array}$ & $\begin{array}{r}0.472 \\
1.356\end{array}$ \\
\hline Number of obs. & 9980 & 9980 & 6471 & 8451 \\
\hline $\begin{array}{r}\chi_{(14)}^{2} \\
\text { Prob }>\chi^{2}\end{array}$ & $\begin{array}{l}128.17 \\
0.0000\end{array}$ & $\begin{array}{l}121.44 \\
0.0000\end{array}$ & $\begin{array}{r}91.10 \\
0.0000\end{array}$ & $\begin{array}{l}200.37 \\
0.0000\end{array}$ \\
\hline
\end{tabular}


Table 2: The effect of relatedness and narrowness on fund performance (t-values below coefficients)

\begin{tabular}{|c|c|c|c|c|}
\hline performance measure & $\begin{array}{r}\text { (1) } \\
\text { dcret }\end{array}$ & $\begin{array}{r}(2) \\
\text { dgret }\end{array}$ & $\begin{array}{r}\text { (3) } \\
\text { alpha }\end{array}$ & $\begin{array}{r}(4) \\
\text { malpha }\end{array}$ \\
\hline related & $\begin{array}{r}1.006 \\
2.309\end{array}$ & $\begin{array}{r}0.918 \\
2.124\end{array}$ & $\begin{array}{r}2.089 \\
2.620\end{array}$ & $\begin{array}{r}0.824 \\
1.667\end{array}$ \\
\hline narrow & $\begin{array}{r}0.018 \\
0.989\end{array}$ & $\begin{array}{r}0.018 \\
0.958\end{array}$ & $\begin{array}{r}0.038 \\
1.277\end{array}$ & $\begin{array}{r}-0.017 \\
-0.645\end{array}$ \\
\hline diffturn & $\begin{array}{r}0.001 \\
1.606\end{array}$ & $\begin{array}{r}0.002 \\
1.755\end{array}$ & $\begin{array}{r}-3.309 \mathrm{E}-04 \\
-0.273\end{array}$ & $\begin{array}{r}0.002 \\
1.591\end{array}$ \\
\hline diffexpense & $\begin{array}{r}-0.005 \\
-0.024\end{array}$ & $\begin{array}{r}0.786 \\
3.480\end{array}$ & $\begin{array}{r}-0.456 \\
-1.160\end{array}$ & $\begin{array}{r}-1.094 \\
-3.926\end{array}$ \\
\hline loaddum & $\begin{array}{r}-0.673 \\
-4.574\end{array}$ & $\begin{array}{r}-0.031 \\
-0.212\end{array}$ & $\begin{array}{r}0.611 \\
2.425\end{array}$ & $\begin{array}{r}-0.114 \\
-0.631\end{array}$ \\
\hline age & $\begin{array}{r}-0.035 \\
-1.976\end{array}$ & $\begin{array}{r}-0.032 \\
-1.844\end{array}$ & $\begin{array}{r}-0.095 \\
-2.830\end{array}$ & $\begin{array}{r}-0.113 \\
-6.398\end{array}$ \\
\hline $\operatorname{age}^{2}$ & $\begin{array}{r}4.217 \mathrm{E}-04 \\
1.521\end{array}$ & $\begin{array}{r}3.791 \mathrm{E}-04 \\
1.359\end{array}$ & $\begin{array}{r}9.101 \mathrm{E}-04 \\
1.908\end{array}$ & $\begin{array}{r}1.341 \mathrm{E}-03 \\
4.962\end{array}$ \\
\hline assets & $\begin{array}{r}-1.903 \mathrm{E}-04 \\
-1.888\end{array}$ & $\begin{array}{r}-1.854 \mathrm{E}-04 \\
-1.845\end{array}$ & $\begin{array}{r}-7.475 \mathrm{E}-04 \\
-4.092\end{array}$ & $\begin{array}{r}-4.642 \mathrm{E}-04 \\
-3.699\end{array}$ \\
\hline assets $^{2}$ & $\begin{array}{r}3.210 \mathrm{E}-08 \\
4.041\end{array}$ & $\begin{array}{r}3.180 \mathrm{E}-08 \\
4.020\end{array}$ & $\begin{array}{r}6.410 \mathrm{E}-08 \\
3.541\end{array}$ & $\begin{array}{r}4.380 \mathrm{E}-08 \\
3.771\end{array}$ \\
\hline assets $^{3}$ & $\begin{array}{r}-5.660 \mathrm{E}-13 \\
-4.561\end{array}$ & $\begin{array}{r}-5.640 \mathrm{E}-13 \\
-4.564\end{array}$ & $\begin{array}{r}-9.750 \mathrm{E}-13 \\
-3.258\end{array}$ & $\begin{array}{r}-6.810 \mathrm{E}-13 \\
-3.657\end{array}$ \\
\hline fund mshare & $\begin{array}{r}-7.042 \\
-5.624\end{array}$ & $\begin{array}{r}-6.987 \\
-5.539\end{array}$ & $\begin{array}{r}-3.229 \\
-1.860\end{array}$ & $\begin{array}{r}-3.739 \\
-2.888\end{array}$ \\
\hline stdv & $\begin{array}{r}0.2307 \\
2.998\end{array}$ & $\begin{array}{r}0.236 \\
3.017\end{array}$ & $\begin{array}{r}0.334 \\
3.652\end{array}$ & $\begin{array}{r}0.259 \\
3.983\end{array}$ \\
\hline family assets & $\begin{array}{r}1.380 \mathrm{E}-05 \\
1.086\end{array}$ & $\begin{array}{r}1.340 \mathrm{E}-05 \\
1.057\end{array}$ & $\begin{array}{r}2.240 \mathrm{E}-05 \\
1.028\end{array}$ & $\begin{array}{r}3.110 \mathrm{E}-05 \\
2.022\end{array}$ \\
\hline family assets ${ }^{2}$ & $\begin{array}{r}-3.060 \mathrm{E}-11 \\
-0.253\end{array}$ & $\begin{array}{r}-3.110 \mathrm{E}-11 \\
-0.258\end{array}$ & $\begin{array}{r}8.870 \mathrm{E}-11 \\
0.465\end{array}$ & $\begin{array}{r}-2.610 \mathrm{E}-10 \\
-1.856\end{array}$ \\
\hline family assets ${ }^{3}$ & $\begin{array}{r}-5.520 \mathrm{E}-17 \\
-0.170\end{array}$ & $\begin{array}{r}-5.060 \mathrm{E}-17 \\
-0.156\end{array}$ & $\begin{array}{r}-6.780 \mathrm{E}-16 \\
-1.413\end{array}$ & $\begin{array}{r}6.290 \mathrm{E}-16 \\
1.702\end{array}$ \\
\hline family assets in cat & $\begin{array}{r}-1.980 \mathrm{E}-06 \\
-0.081\end{array}$ & $\begin{array}{r}-1.460 \mathrm{E}-06 \\
-0.059\end{array}$ & $\begin{array}{r}-4.720 \mathrm{E}-05 \\
-0.966\end{array}$ & $\begin{array}{r}-1.370 \mathrm{E}-05 \\
-0.511\end{array}$ \\
\hline family funds in cat & $\begin{array}{r}-0.066 \\
-1.513\end{array}$ & $\begin{array}{r}-0.069 \\
-1.567\end{array}$ & $\begin{array}{r}0.063 \\
0.791\end{array}$ & $\begin{array}{r}-0.007 \\
-0.124\end{array}$ \\
\hline funds in cat & $\begin{array}{r}4.294 \mathrm{E}-04 \\
1.310\end{array}$ & $\begin{array}{r}3.395 \mathrm{E}-04 \\
1.037\end{array}$ & $\begin{array}{r}-0.003 \\
-6.594\end{array}$ & $\begin{array}{r}-0.003 \\
-7.222\end{array}$ \\
\hline constant & $\begin{array}{r}0.217 \\
0.622\end{array}$ & $\begin{array}{r}0.175 \\
0.498\end{array}$ & $\begin{array}{r}0.436 \\
0.815\end{array}$ & $\begin{array}{r}1.147 \\
3.455\end{array}$ \\
\hline $\begin{array}{r}\text { Number of obs. } \\
\chi^{2}{ }_{(15)} \\
\text { Prob. }>\chi_{(15)}^{2}\end{array}$ & $\begin{array}{r}9980 \\
119.89 \\
0.0000\end{array}$ & $\begin{array}{r}9980 \\
104.98 \\
0.0000\end{array}$ & $\begin{array}{r}6471 \\
90.08 \\
0.0000\end{array}$ & $\begin{array}{r}8451 \\
191.56 \\
0.0000\end{array}$ \\
\hline
\end{tabular}


Table 3: The effect of focus on cash inflows into families

(t-statistics below coefficients)

\begin{tabular}{|c|c|c|c|c|c|c|c|}
\hline $\begin{array}{l}\text { dependent variable for } \\
\text { all regressions: } \\
\text { famflow }\end{array}$ & $\begin{array}{r}\text { (1) } \\
\text { past } \\
\text { performance } \\
\text { based on } \\
\text { dcret }\end{array}$ & $\begin{array}{c}\text { (2) } \\
\text { past perf. } \\
\text { based on } \\
\text { malpha }\end{array}$ & $\begin{array}{r}\text { (3) } \\
\text { past perf. } \\
\text { based on } \\
\text { ranking on } \\
\text { adj. total } \\
\text { returns }\end{array}$ & $\begin{array}{r}\text { (4) } \\
\text { past perf. } \\
\text { based on } \\
\text { ranking on } \\
\text { adj. total } \\
\text { returns }\end{array}$ & $\begin{array}{r}\mathbf{( 5 )} \\
\text { past perf. } \\
\text { based on } \\
\text { ranking on } \\
\text { malpha }\end{array}$ & $\begin{array}{r}\text { (6) } \\
\text { past perf. } \\
\text { based on } \\
\text { ranking on } \\
\text { malpha }\end{array}$ & $\begin{array}{l}\text { (7) } \\
\text { no past } \\
\text { perf. } \\
\text { measure } \\
\text { included }\end{array}$ \\
\hline focus & $\begin{array}{r}-1008.779 \\
-2.513\end{array}$ & $\begin{array}{r}-991.246 \\
-2.466\end{array}$ & $\begin{array}{r}-966.818 \\
-2.408\end{array}$ & $\begin{array}{r}-986.613 \\
-2.399\end{array}$ & $\begin{array}{r}-963.399 \\
-2.396\end{array}$ & $\begin{array}{r}-1075.524 \\
-2.599\end{array}$ & $\begin{array}{r}-996.085 \\
-2.479\end{array}$ \\
\hline $\begin{array}{l}\text { average past } \\
\text { performance }\end{array}$ & $\begin{array}{r}17.871 \\
1.886\end{array}$ & $\begin{array}{r}5.460 \\
0.675\end{array}$ & $\begin{array}{r}463.697 \\
2.034\end{array}$ & & $\begin{array}{r}397.294 \\
1.655\end{array}$ & & \\
\hline $\begin{array}{l}\text { average low } \\
\text { performance }\end{array}$ & & & & $\begin{array}{r}-581.134 \\
-0353\end{array}$ & & $\begin{array}{r}-1440.007 \\
-1.299\end{array}$ & \\
\hline $\begin{array}{l}\text { average medium } \\
\text { performance }\end{array}$ & & & & $\begin{array}{r}613.837 \\
2.027\end{array}$ & & $\begin{array}{r}812.632 \\
2.470\end{array}$ & \\
\hline $\begin{array}{l}\text { average high } \\
\text { performance }\end{array}$ & & & & $\begin{array}{r}-315.948 \\
-0.179\end{array}$ & & $\begin{array}{r}-2630.046 \\
-0 / 675\end{array}$ & \\
\hline family assets & $\begin{array}{r}-0.051 \\
-2.490\end{array}$ & $\begin{array}{r}-0.051 \\
-2.501\end{array}$ & $\begin{array}{r}-0.050 \\
-2.444\end{array}$ & $\begin{array}{r}-0.050 \\
-2.442\end{array}$ & $\begin{array}{r}-0.052 \\
-2.554\end{array}$ & $\begin{array}{r}-0.053 \\
-2.601\end{array}$ & $\begin{array}{r}-0.051 \\
-2.488\end{array}$ \\
\hline family assets $^{2}$ & $\begin{array}{r}2.17 \mathrm{E}-06 \\
9.714\end{array}$ & $\begin{array}{r}2.17 \mathrm{E}-06 \\
9.725\end{array}$ & $\begin{array}{r}2.16 \mathrm{E}-06 \\
9.667\end{array}$ & $\begin{array}{r}2.15 \mathrm{E}-06 \\
9.656\end{array}$ & $\begin{array}{r}2.18 \mathrm{E}-06 \\
9.758\end{array}$ & $\begin{array}{r}2.18 \mathrm{E}-06 \\
9.762\end{array}$ & $\begin{array}{r}2.17 \mathrm{E}-06 \\
9.724\end{array}$ \\
\hline family assets ${ }^{3}$ & $\begin{array}{r}-6.91 \mathrm{E}-12 \\
-10.824\end{array}$ & $\begin{array}{r}-6.92 \mathrm{E}-12 \\
-10.837\end{array}$ & $\begin{array}{r}-6.88 \mathrm{E}-12 \\
-10.781\end{array}$ & $\begin{array}{r}-6.88 \mathrm{E}-12 \\
-10.767\end{array}$ & $\begin{array}{r}-6.93 \mathrm{E}-12 \\
-10.859\end{array}$ & $\begin{array}{r}-6.92 \mathrm{E}-12 \\
-10.849\end{array}$ & $\begin{array}{r}-6.92 \mathrm{E}-12 \\
-10.840\end{array}$ \\
\hline average age & $\begin{array}{r}-73.772 \\
-1.912\end{array}$ & $\begin{array}{r}-73.096 \\
-1.892\end{array}$ & $\begin{array}{r}-77.244 \\
-2.000\end{array}$ & $\begin{array}{r}-74.201 \\
-1.907\end{array}$ & $\begin{array}{r}-89.536 \\
-2.247\end{array}$ & $\begin{array}{r}-75.783 \\
-1.851\end{array}$ & $\begin{array}{r}-73.171 \\
-1.894\end{array}$ \\
\hline average age $^{2}$ & $\begin{array}{r}0.734 \\
1.181\end{array}$ & $\begin{array}{r}0.726 \\
1.166\end{array}$ & $\begin{array}{r}0.768 \\
1.235\end{array}$ & $\begin{array}{r}0.712 \\
1.137\end{array}$ & $\begin{array}{r}0.928 \\
1.465\end{array}$ & $\begin{array}{r}0.726 \\
1.119\end{array}$ & $\begin{array}{r}0.727 \\
1.168\end{array}$ \\
\hline average diffexpense & $\begin{array}{r}-446.580 \\
-1.646\end{array}$ & $\begin{array}{r}-461.467 \\
-1.699\end{array}$ & $\begin{array}{r}-451.134 \\
-1.663\end{array}$ & $\begin{array}{r}-452.275 \\
-1.664\end{array}$ & $\begin{array}{r}-463.000 \\
-1.706\end{array}$ & $\begin{array}{r}-453.458 \\
-1.672\end{array}$ & $\begin{array}{r}-461.245 \\
-1.698\end{array}$ \\
\hline average stdv & $\begin{array}{r}-33.300 \\
-0.876\end{array}$ & $\begin{array}{r}-28.852 \\
-0.754\end{array}$ & $\begin{array}{r}-43.103 \\
-1.111\end{array}$ & $\begin{array}{r}-36.818 \\
-0.924\end{array}$ & $\begin{array}{r}-35.818 \\
-0.934\end{array}$ & $\begin{array}{r}-30.755 \\
-0.799\end{array}$ & $\begin{array}{r}-24.847 \\
-0.657\end{array}$ \\
\hline av. category flow & $\begin{array}{r}1235.735 \\
8.603\end{array}$ & $\begin{array}{r}1224.479 \\
8.522\end{array}$ & $\begin{array}{r}1223.369 \\
8.528\end{array}$ & $\begin{array}{r}1229.771 \\
8.514\end{array}$ & $\begin{array}{r}1231.505 \\
8.574\end{array}$ & $\begin{array}{r}1213.881 \\
8.438\end{array}$ & $\begin{array}{r}1223.423 \\
8.517\end{array}$ \\
\hline average funds in cat & $\begin{array}{r}-0.447 \\
-0.617\end{array}$ & $\begin{array}{r}-0.414 \\
-0.570\end{array}$ & $\begin{array}{r}-0.447 \\
-0.617\end{array}$ & $\begin{array}{r}-0.421 \\
-0.581\end{array}$ & $\begin{array}{r}-0.447 \\
-0.617\end{array}$ & $\begin{array}{r}-0.426 \\
-0.589\end{array}$ & $\begin{array}{r}-0.446 \\
-0.616\end{array}$ \\
\hline constant & $\begin{array}{r}1615.365 \\
3.380\end{array}$ & $\begin{array}{r}1590.912 \\
3.326\end{array}$ & $\begin{array}{r}1441.889 \\
2.985\end{array}$ & $\begin{array}{r}1565.017 \\
2.904\end{array}$ & $\begin{array}{r}1632.431 \\
3.411\end{array}$ & $\begin{array}{r}1786.837 \\
3.664\end{array}$ & $\begin{array}{r}1589.659 \\
3.324\end{array}$ \\
\hline $\begin{array}{l}\text { obs. } \\
\mathbf{R}^{2}\end{array}$ & $\begin{array}{r}1338 \\
0.453\end{array}$ & $\begin{array}{r}1338 \\
0.453\end{array}$ & $\begin{array}{r}1338 \\
0.449\end{array}$ & $\begin{array}{r}1338 \\
0.452\end{array}$ & $\begin{array}{r}1338 \\
0.431\end{array}$ & $\begin{array}{r}1338 \\
0.443\end{array}$ & $\begin{array}{r}1338 \\
0.454\end{array}$ \\
\hline
\end{tabular}




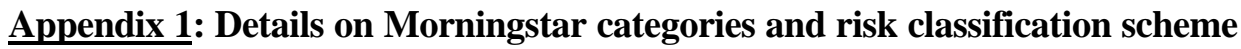

Equity fund investment style categories:

\begin{tabular}{|c|c|c|c|}
\hline \multicolumn{3}{|c|}{ Investment Style } & \multirow{2}{*}{$\begin{array}{l}\text { Median } \\
\text { Market } \\
\text { Capitalization }\end{array}$} \\
\hline Value & Blend & Growth & \\
\hline $\begin{array}{l}\text { Larae-cap } \\
\text { Value }\end{array}$ & $\begin{array}{l}\text { Larae-can } \\
\text { Blend }\end{array}$ & $\begin{array}{l}\text { Larae-cao } \\
\text { Growth }\end{array}$ & Large \\
\hline $\begin{array}{l}\text { Mid-can } \\
\text { Value }\end{array}$ & $\begin{array}{l}\text { Mid-cap } \\
\text { Blend }\end{array}$ & $\begin{array}{l}\text { Mid-cap } \\
\text { Growth }\end{array}$ & Medium \\
\hline $\begin{array}{l}\text { Small-cap } \\
\text { Value }\end{array}$ & $\begin{array}{l}\text { Small-cap } \\
\text { Blend }\end{array}$ & $\begin{array}{l}\text { Small-cap } \\
\text { Growth }\end{array}$ & Small \\
\hline
\end{tabular}

Funds are classified as follows:

Let IS $=($ average $\mathrm{P} / \mathrm{E}$ ratio of fund $/$ average $\mathrm{P} / \mathrm{E}$ ratio of S\&P 500) + (average P/book ratio of fund / average $\mathrm{P} /$ book ratio of S\&P 500)

If IS $<1.75$, the fund is classified as Value.

If IS lies between 1.75 and 2.25 , the fund is classified as Blend.

If IS > 2.25, the fund is classified as Growth.

Let $\mathrm{MMC}=$ median market capitalization $=$ half of the fund's assets are invested in stocks of companies larger than MMC

If MMC $<\$ 1$ billion, the fund is classified as Small-Cap.

If MMC lies between $\$ 1$ billion and \$5 billion, the fund is classified as Medium-Cap.

If MMC > $\$ 5$ billion, the fund is classified as Large-Cap.

For international equity funds, IS is defined on the basis of average price/cash flow and average price/book ratios relative to the MSCI EAFE index. The same cut-off points apply. The vertical axis is identical.

Bond fund investment style categories:

Investment Style

\begin{tabular}{|c|c|c|c|}
\hline $\begin{array}{l}\text { Short- } \\
\text { term }\end{array}$ & $\begin{array}{l}\text { Interm- } \\
\text { term }\end{array}$ & $\begin{array}{l}\text { Long- } \\
\text { term }\end{array}$ & Quality \\
\hline $\begin{array}{l}\text { Short-term } \\
\text { Hiah } \\
\text { Quality }\end{array}$ & $\begin{array}{l}\text { Interm-term } \\
\text { Hiah } \\
\text { Quality }\end{array}$ & $\begin{array}{l}\text { Lona- } \\
\text { term Hiah } \\
\text { Qualitv }\end{array}$ & High \\
\hline $\begin{array}{l}\text { Short-term } \\
\text { Medium } \\
\text { Qualitv }\end{array}$ & $\begin{array}{l}\text { Interm-term } \\
\text { Medium } \\
\text { Qualitv }\end{array}$ & $\begin{array}{l}\text { Lona-term } \\
\text { Medium } \\
\text { Qualitv }\end{array}$ & Medium \\
\hline $\begin{array}{l}\text { Short-term } \\
\text { Low } \\
\text { Quality }\end{array}$ & $\begin{array}{l}\text { Interm-term } \\
\text { Low } \\
\text { Quality }\end{array}$ & $\begin{array}{l}\text { Lona-term } \\
\text { Low } \\
\text { Quality }\end{array}$ & Low \\
\hline
\end{tabular}

Funds are classified as follows:

Let $\mathrm{AEM}=$ average effective maturity of a fund $=$ weighted average of all bonds' maturities, using asset size as weight.

If AEM $<4$ years, the fund is classified as ShortTerm.

If AEM lies between 4 and 10 years, the fund is classified as Intermediate-Term.

If AEM > 10 years, the fund is classified as Long-Term.

Funds that have an average credit rating of AAA or AA are classified as High Quality. Funds that have an average credit rating of A, BB, or BBB are classified as Medium Quality. Funds that have an average credit rating of less than BBB are classified as Low Quality.

source: Morningstar (1996) 


\section{Appendix 2: Morningstar categories and associated market benchmarks}

\author{
Morningstar Categories \\ Convertible Bond \\ Diversified Emerging Markets \\ Diversified Pacific Stock \\ Domestic Hybrid \\ Europe Stock \\ Foreign Stock \\ High Yield Bond \\ Intermediate-Term Bond \\ Intermediate-Term Government \\ International Bond \\ International Hybrid \\ Japan Stock \\ Large Blend \\ Large Growth \\ Large Value \\ Latin America Stock \\ Long-Term Bond \\ Long-Term Government \\ Mid-Cap Blend \\ Mid-Cap Growth \\ Mid-Cap Value \\ Multisector Bond \\ Muni National Intermediate \\ Muni National Long-Term \\ Muni Short Term \\ Muni Single-State Intermediate \\ Muni Single-State Long \\ Pacific ex-Japan Stock \\ Short-Term Bond \\ Short-Term Government \\ Small Blend \\ Small Growth \\ Small Value \\ Specialty-Communications \\ Specialty-Financial \\ Specialty-Health Care \\ Specialty-Natural Resources \\ Specialty-Precious Metals \\ Specialty-Real Estate \\ Specialty-Technology \\ Specialty-Unaligned \\ Specialty-Utilities \\ Ultrashort Bond \\ World Stock
}

\section{Market Benchmark}

1985 Lehman Bros Agg, 1986-1996 Convertible Bond Index 1985-1988 MSCI Pacific; 1989-1996 MSCI Emerging Markets Morgan Stanley Country Index (MSCI) Pacific

S\&P 500

1985 MSCI World, 1986-1996 MSCI Europe

MSCI EAFE

1985 Lehman Bros Agg, 1986-1996 First Boston High Yield

1985-1988 Lehman Bros Agg, 89-96 Lehman Bros Int Govt/Corp Lehman Bros Govt

Salomon Brothers World Govt

MSCI World

MSCI Japan

S\&P 500

Wilshire LG

Wilshire LV

MSCI Latin America

1985 Lehman Bros Agg, 86-96 Lehman Bros LT Gov/Corp

1985 Lehman Bros Agg, 86-96 Lehman Bros LT Gov/Corp

S\&P Midcap 400

Wilshire MG

S\&P Midcap 400

1985 Lehman Bros Agg, 1986-1996 First Boston High Yield

Lehman Bros Muni

Lehman Bros Muni

Lehman Bros Muni

Lehman Bros Muni

Lehman Bros Muni

1985-1987 MSCI Pacific; 1988-1996 MSCI FE ex Japan

Lehman Bros 1-3 Govt

Lehman Bros 1-3 Govt

Russell 2000

Russell 2000

Russell 2000

1985 S\&P 500, 1986-1996 Wilshire 5000

S\&P 500

1985 S\&P 500, 1986-1996 Wilshire 5000

1985 S\&P 500, 1986-1996 Wilshire 5000

1985 S\&P 500, 1986-1996 Wilshire 5000

Wilshire REIT

1985 S\&P 500, 1986-1996 Wilshire 5000

1985 S\&P 500, 1986-1996 Wilshire 5000

Wilshire LV

Lehman Bros 1-3 Govt

MSCI World 


\section{References}

Baumol, William J., Steven M. Goldfield, Lilli A. Gorden, and Michael F. Koehn. 1990. The Economics of Mutual Fund Markets: Competition versus Regulation. Boston: Kluwer Academic.

Blake, Christopher R., Edwin J. Elton, and Martin Gruber. 1993. "The Performance of Bond Funds." Journal of Business 66 (3): 371-403.

Brown, Keith C., W.V. Harlow, and Laura T. Starks. 1996. "Of Tournaments and Temptations: An Analysis of Managerial Incentives in the Mutual Fund Industry." Journal of Finance 51 (1): 85110.

Brown, Stephen J., and William N. Goetzman. 1995. "Performance Persistence.” Journal of Finance 50 (2): 679--698.

Brown, Stephen J., William N. Goetzman, Roger G. Ibbotson, and Stephen A. Ross. 1992. "Survivorship Bias in Performance Studies." Review of Financial Studies 5 (4): 553-580.

Brynjolfsson, Erik, and Lorin Hitt. 1996. "Information Technology and Organizational Architecture: An Exploratory Analysis." (working paper).

Caves, Richard E., Michael E. Porter, A. Michael Spence, and J. T. Scott. 1980. Competition in the Open Economy. Cambridge: Harvard University Press.

Chevalier, Judith, and Glenn Ellison. 1997. "Risk Taking by Mutual Funds as a Response to Incentives." Journal of Political Economy 105 (6): 1167-1200.

Comment, Robert, and Gregg A. Jarrell. 1995. "Corporate Focus and Stock Returns." Journal of Financial Economics 37: 67-87.

Daley, Lane, Vikas Mehotra, and Ranjini Sivakumar. 1997. "Corporate Focus and Value Creation: Evidence from Spinoffs.” Journal of Financial Economics 45 (2): 257-281.

Eaton. Leslie. 1995. "A Bond Strategy Too Clever by Half; Fidelity Stumbles in an Attempt to Repeat Its Success With Stock Funds.” New York Times, May 3.

Elton, Edwin J., Martin J. Gruber, Sanjiv Das, and Matthew Hlavka. 1993. "Efficiency with Costly Information: A Reinterpretation of Evidence from Managed Portfolios." Review of Financial Studies 6 (1): 1-22.

Ferris, Stephen P., and Don M. Chance. 1987. "The Effect of 12b-1 Plans on Mutual Fund Expense Ratios: A Note." Journal of Finance 62 (4): 1077-1082.

Gasparino, Charles. 1997. “Do Fund Mergers Hurt Small Investors?” Wall Street Journal, July 8: C1.

Gruber, Martin J. 1996. "Another Puzzle: The Growth in Actively Managed Mutual Funds." Journal of Finance 51 (3): 783-810.

Hoshi, Takeo, Anil Kashyap, and David Scharfstein. 1991. "Corporate Structure, Liquidity, and Investment: Evidence from Japanese Industrial Groups.” Quarterly Journal of Economics 106: 33$\underline{60 .}$

Huber, P. J. 1967. "The Behavior of Maximum Likelihood Estimates Under Non-Standard Conditions." in Proceedings of the Fifth Berkeley Symposium in Mathematical Statistics and Probability, 221-233. Berkeley: University of California Press. 
Ichniowski, Casey, Kathryn Shaw, and Giovanno Prennushi. 1997. "The Effects of Human Resource Management Practices on Productivity: A Study of Steel Finishing Lines." American Economic Review 87 (3): 291-313.

Ippolito, Richard. A. 1989. "Efficiency with Costly Information: A Study of Mutual Fund Performance, 1965-84.” Quarterly Journal of Economics 104: 1-23.

Jensen, Michael C. 1968. "The Performance of Mutual Funds in the Period 1945-1964." Journal of Finance 23: 389-416.

John, Kose, and Eli Ofek. 1995. "Asset Sales and Increase in Focus." Journal of Financial Economics 37:105-126.

Lang, Larry H. P., and René M. Stulz. 1994. "Tobin's q, Corporate Diversification, and Firm Performance." Journal of Political Economy 102 (6): 1248-1280.

Liang, K.-Y., and S.L. Zeger. 1986. "Longitudinal Data Analysis Using Generalized Linear Models." Biometrika 73: 13-22.

Lichtenberg, Frank R. 1992. "Industrial De-Diversification and its Consequences for Productivity." Journal of Economic Behavior and Organization 18: 427-438.

Makadok, Richard, and Gordon Walker. 1996. "Search and Selection in the Money Market Fund Industry.” Strategic Management Journal 17: 39-54.

Malkiel, Burton G. 1995. "Returns from Investing in Equity Mutual Funds 1971-1991.” Journal of Finance 50: 549-572.

Meyer, Margaret, Paul Milgrom, and John D. Roberts. "Organizational Prospects, Influence Costs, and Ownership Changes.” Journal of Economics and Management Strategy 1 (1): 10-35.

Milgrom, Paul, and John Roberts. 1990. "The Economics of Modern Manufacturing: Technology, Strategy, and Organization.” American Economic Review 80 (3): 511-528.

- 1995. "Complementarities and Fit: Strategy, Structure, and Organizational Change in Manufacturing." Journal of Accounting and Economics 19: 179-208.

Montgomery, Cynthia. 1985. "Product-Market Diversification and Market Power." Academy of Management Journal 28: 789-798.

1994. “Corporate Diversification.” Journal of Economic Perspectives 8 (3): 163-178.

, and Birger Wernerfelt. 1988. "Diversification, Ricardian Rents, and Tobin's q." RAND Journal of Economics 19: 623-632.

Morck, Randall, Andrei Shleifer, and Robert W. Vishny. 1990. "Do Managerial Objectives Drive Bad Acquisitions?" Journal of Finance 45 (1): 31-48.

Morningstar. 1996. User's Guide to Morningstar Mutual Funds.

Palepu, Krishna. 1985. "Diversification Strategy, Profit Performance and the Entropy Measure." Strategic Management Journal 6: 239-255.

Penrose, Edith T. 1959. The Theory of the Growth of the Firm. Oxford: Basil Blackwell.

Porter, Michael E. 1996. "What is Strategy?" Harvard Business Review 74 (November-December): 61-78. 
Rotemberg, Julio J., and Garth Saloner. 1994. "Benefits of Narrow Business Strategies." American Economic Review 84 (5): 1330-1349.

Rumelt, Richard P. 1974. Strategy, Structure, and Economic Performance. Cambridge: Harvard University Press.

—. 1982. "Diversification Strategy and Profitability." Strategic Management Journal 3: 359-369.

Scherer, Frederick M., and Ravenscraft, David J. 1987. Mergers, Sell-Offs, and Economic Efficiency. Washington, D.C.: The Brookings Institution.

Schmalensee, Richard. 1985. "Do Markets Differ Much?” American Economic Review 75: 341-351.

Sirri, Eric, and Peter Tufano. 1998. "Costly Search and Mutual Fund Flows." Journal of Finance 53 (5): $1589-1622$.

Teece, David J. 1982. "Towards an Economic Theory of the Multiproduct Firm.” Journal of Economic Behavior and Organization 3: 39-63.

Tufano, Peter, and Matthew Sevick. 1997. "Board Structure and Fee-Setting in the U.S. Mutual Fund Industry." Journal of Financial Economics 46: 321-355.

Wernerfelt, Birger, and Cynthia A. Montgomery. 1988. “Tobin's $q$ and the Importance of Focus in Firm Performance." American Economic Review 78 (1): 246-250.

White, H. 1980. "A Heteroskedasticity-Consistent Covariance Matrix Estimator and a Direct Test for Heteroskedasticity." Econometrica 48: 1-25.

You, Victor L., Richard E. Caves, James S. Henry, and Michael M. Smith. 1986. "Mergers and Bidders' Wealth: Managerial and Strategic Factors." in The Economics of Strategic Planning, edited by L.G. Thomas, 201-221. Boston: Lexington Books. 


\section{Footnotes}

${ }^{1}$ Within the context of studying inter-industry diversification, some authors have tackled this problem by analyzing the effects of diversification at the level of business groups which are composed of individual firms for which data is available (Hoshi, Kashyap, and Scharfstein 1991).

2 In the strategic management literature, Rumelt $(1974,1982)$ further explores the relationship between the type of diversification and firm performance. By adopting categorical measures of diversification, Rumelt extends the classification of firms beyond one-dimensional diversification measures. He finds that firms pursuing related diversification perform better than firms pursuing unrelated diversification.

${ }^{3}$ Related empirical work, which also uses the logic of complementarities, albeit on much more tightly defined domains, includes Brynjolfsson and Hitt (1996), and Ichniowski, Shaw, and Prennushi (1997).

${ }^{4}$ These authors also show that influence costs are likely to be smaller for firms with related divisions. Hence, their model includes benefits of relatedness as well.

${ }^{5}$ Besides outsourcing the investment function, the fund board also contracts with a custodian, a transfer agent, and a principal underwriter. The custodian is in charge of physically holding the securities owned by the fund. The transfer agent is responsible for record-keeping services for fund shareholders, including distributing dividends and capital gains to fund shareholders. Lastly, the principal underwriter is in charge of selling the shares of the fund to individuals or institutions. Some investment management companies provide the record-keeping and underwriting services themselves, while others use third-party providers for distribution and underwriting.

${ }^{6}$ Chevalier and Ellison (1997) further show that the relationship between past performance and cash inflows is positive and convex. Since cash inflows are tied to compensation, fund managers face in essence an option. By increasing the variance of returns, fund managers increase the value of this option while imposing a higher risk on fund shareholders.

${ }^{7}$ These culture differences can also make mergers of families difficult. The Wall Street Journal reports: "Successful fund companies are often products of their managers' personalities, the organization's distinct cultures and other intangibles which may be wiped out in a big merger. These characteristics often color the companies' approaches to investing, marketing and dealing with shareholders" (Gasparino 1997).

${ }^{8}$ I am grateful to Timothy Duncanson for providing this example.

${ }^{9}$ For evidence on the existence of scale economies in the mutual fund industry see, e.g., Baumol et al. (1990).

${ }^{10}$ A measure that is based only on the diversity of funds offered by a family certainly does not capture all choices a fund family is making. Some of the misalignments described above can be alleviated, for instance, by outsourcing the investment management for funds that do not fit into the culture of the family. In general, however, fund families are very reluctant to outsource the most profitable part of their business. For instance, Fidelity did not outsource the investment management of any fund until June 1997 , when it announced that Bankers Trust would manage Fidelity's index funds.

${ }^{11}$ As a matter of fact, by 1996 , only $4.4 \%$ of all assets in domestic equity funds and less than $1 \%$ of assets in domestic bond funds were in index funds.

${ }^{12}$ Since loads are one-time fees, we need to amortize them over the average time customers hold their fund shares. In short, we compute average holding times from sales and redemption data available from the Investment Company Institute's Mutual Fund Yearbooks for each prospectus objective for each of the years 1985-1996 and average them over time. Holding times varied from 2.7 years for "Precious Metal" funds to 10.2 years for "Asset Allocation" funds. Following Sirri and Tufano (1998), we then adjust the fund returns by dividing the sales load by the average holding time for its respective prospectus objective 
and subtracting this annualized sales load from the yearly return. A similar adjustment was made for deferred loads. Further details of the adjustments are available from the author.

${ }^{13}$ The annual expense ratio is the percentage of assets deducted for fund expenses, including management fees, $12 \mathrm{~b}-1$ fees, administrative fees and operating costs. It does not include portfolio transaction fees, brokerage costs, and initial or deferred sales charges.

${ }^{14}$ In constructing $a l p h a_{i t}$ using equations (3) and (4) it is implicitly assumed that the betas of the funds are constant from year to year. In a study of all equity funds over the period 1971-1991, Malkiel (1995) finds "reasonable stability in the betas of mutual funds over time." Similar results are reported by Ippolito (1989). Some studies suggest that managers might, however, change the riskiness of the funds strategically over the course of a year (Brown, Harlow, and Starks 1996, Chevalier and Ellison 1997). To achieve reliable estimates of $\beta_{\mathrm{i}}$, funds were only included if they were older than six years.

${ }^{15}$ Both the equity- and bond-multi-index models include only U.S. "factors." As a result, for this performance variable all international funds are dropped from the analysis.

${ }^{16}$ Ordinary least squares would correspond to letting $\mathrm{R}_{\mathrm{t}, \mathrm{s}}=1$ if $\mathrm{t}=\mathrm{s}$, and 0 otherwise. A random-effects model would correspond to letting $\mathrm{R}_{\mathrm{t}, \mathrm{s}}=1$ if $\mathrm{t}=\mathrm{s}$, and $\rho$ otherwise; and an $\mathrm{AR}(1)$ model would correspond to letting $R_{t, s}=1$ if $t=s$, and $\rho^{|t-s|}$ otherwise.

${ }^{17}$ For all variables that include category measures, i.e., diffturnover, diffexpense, fund mshare, and funds in cat, we use category measures as reported by Morningstar. Thus, these measures, e.g., the mean category expense ratio and the mean category turnover, do not represent sample means, but take into account virtually all funds that existed in the particular category in the respective year.

${ }^{18}$ Even if we concentrate only on the positive loaddum coefficient in regression (3), the result would imply that given a typical sales load of 5\%, the investor would have to hold on to the fund close to 10 years to derive a benefit from the load fund.

${ }^{19}$ Another issue which is featured prominently in the literature on absolute fund performance and performance persistence is survivorship bias (e.g., Brown et al. 1992). Survivorship bias is particularly a problem for studies that test whether fund managers are able to add value, i.e., whether funds generate higher than market returns. In this study, however, the effect of the survivorship bias is ambiguous. If the hypothesis is correct that funds with high values of related perform better than funds with a low measure, we would expect to have more missing, poorly performing funds that were lone stragglers than funds which had high values of related. (Brown and Goetzman (1995) show that—not too surprisingly—poorly performing funds have a greater probability of disappearing than funds with high performance.) Yet, since more poorly performing funds with low values of related are missing in the data than poorly performing funds with high values of related, the results are biased against finding a relatedness effect. Unfortunately, if the hypothesis is incorrect, then we would expect to miss more poorly performing highrelatedness funds than low-relatedness funds, and the results would be biased towards finding a positive relatedness effect. Given our results, however, this bias would have to be extremely strong, because it would have to both overpower the true negative effect and generate the observed positive relationship.

${ }^{20}$ As a matter of fact, both Chevalier and Ellison (1997) and Sirri and Tufano (1998) study the relationship between past performance and the growth rate of inflows into families, thereby controlling indirectly for size. Since we are interested in the incentives of family owners and fees are proportional to asset size, we felt it was more natural to measure flows in net dollars and control for size directly, rather than assuming a linear relationship between family size and cash flows. 